\title{
PERLINDUNGAN HUKUM TERHADAP PEKERJA YANG MENGALAMI PELECEHAN SEKSUAL DALAM RANGKA MEWUJUDKAN BELA NEGARA
}

Rosalia Dika Agustanti, Satino, Rildo Rafael Bonauli; Fakultas Hukum UPN Veteran Jakarta, Jakarta; E-mail: rosaliadika@upnvj.ac.id, satino@upnvj.ac.id, rildorafael0@gmail.com

\begin{abstract}
Abstrak
Wacana penegakan HAM terus meningkat, tetapi pada stigmatisasi seksualitas perempuan, tampaknya masih mengakar dalam budaya masyarakat. Pandangan dikotomis ini pada akhirnya mempersulit perempuan untuk mengakses hak-hak mereka, baik ketika masyarakat maupun pihak berwenang menempatkan perempuan sebagai korban kejahatan. Kenyamanan kerja sangat berpengaruh dalam menciptakan hubungan kerja yang kondusif. Salah satu hal yang perlu diingat dalam menciptakan kenyamanan kerja adalah adanya kondisi kerja tanpa diskriminasi termasuk pelecehan seksual di tempat kerja.. Tindakan ini dapat berlangsung antara pekerja/atasan dan seorang pekerja lain (hubungan vertikal) atau antara pekerja dengan pekerja (hubungan horizontal), antara pemberi kerja dengan pekerja kontrak atau pekerja outsourcing dan antara pekerja/penyedia jasa dengan klien/pihak ketiga. Metode penelitian yang digunakan dalam penelitian ini adalah metode penelitian yuridis normatif. Pendekatan yang digunakan adalah pendekatan Perundang-undangan, Pendekatan Konseptual, dan Pendekatan Kasus. Penelitian dimulai dengan mengkaji dan menganalisis terlebih dahulu mengenai bentuk pelecehan seksual seperti apa yang sering diterima oleh pekerja, dan berapa banyak pekerja yang mendapatkan pelecehan seksual. Selanjutnya analisa dilakukan terhadap ada tidaknya tindakan yang dilakukan pemerintah dalam hal ini Kementerian Ketenagakerjaan untuk menertibkan banyaknya kasus pelecehan seksual oleh pekerja yang tidak semuanya selesai di Pengadilan. Kemudian penelitian ini dilanjutkan dengan menganalisis bentuk perlindungan hukum terhadap korban yang mengalami pelecean seksual, apakah sudah terpenuhi atau belum. Dalam menganalisa permasalahan, peneliti menggunakan pendekatan kasus, terkait adanya pelecehan seksual di tempat kerja yang dilakukan oleh pekerja.
\end{abstract}

Kata Kunci: Pertanggungjawaban Pidana; Pelecehan Seksual; Pekerja

\begin{abstract}
The discourse on human rights enforcement continues to increase, but in the stigmatization of female sexuality, it seems that it is still rooted in the culture of society. This dichotomous view ultimately makes it difficult for women to access their rights, both when the community and the authorities place women as victims of crime. Feeling comfortable at work is very influential in creating a conducive working relationship. One of the things to keep in mind in creating comfortable working environment is the existence of working conditions without discrimination including sexual harassment in the workplace. This action can take place between an employer and other workers (vertical relationship) or among the workers (horizontal relations), between employers and contract workers or outsourced workers and between workers / service providers and clients / third parties. The research method used in this study is a normative juridical research method. The approach used is the Legislative Approach, Conceptual Approach, and Case Approach. The research begins by reviewing and analyzing in advance what forms of sexual harassment workers often receive, and how many workers are sexually abused. Furthermore, an analysis is carried out on the presence or absence of actions taken by the government in this case the Ministry of Manpower to curb the number of cases of sexual harassment by workers which are not all finished in the Court. Then this research continues by analyzing the forms of legal protection for victims who have experienced sexual harassment, whether or not they have been fulfilled. In analyzing the problem, researchers used a case approach, related to sexual harassment in the workplace committed by workers.
\end{abstract}

Keywords: Criminal Liability; Sexual Harassment; The Worker 


\section{PENDAHULUAN}

\section{Latar Belakang}

Pengakuan atas dasar prinsip persamaan kesempatan bagi laki-laki dan perempuan dalam memperoleh hak untuk hidup tanpa takut akan kekejaman dan pelecehan sebagaimana diatur dalam Undang-Undang Dasar Negara Republik Indonesia Tahun 1945 Pasal 27 ayat (2) yang berbunyi "Setiap warga negara berhak untuk pekerjaan dan kehidupan yang layak bagi kemanusiaan "dan pasal 28 I ayat (2) yang berbunyi" Setiap orang memiliki hak untuk bebas dari pengaruh diskriminasi untuk alasan apa pun dan berhak atas perlindungan terhadap diskriminasi semacam itu".

Hukum pada dasarnya merupakan dari cerminan hak asasi manusia, sehingga hukum mengandung keadilan dan atau tidak ditentukan oleh hak asasi manusia yang terkandung dan diatur atau dijamin oleh hukum. Undang-undang tersebut tidak lagi dilihat sebagai refleksi kekuasaan semata, tetapi juga harus memancarkan perlindungan terhadap hak-hak warga negara. Hukum yang didasarkan pada nilai-nilai kemanusiaan mencerminkan norma-norma yang menghormati martabat manusia dan mengakui hak asasi manusia. Hak asasi manusia merupakan alat untuk memungkinkan warga masyarakat dengan bebas mengembangkan bakatnya untuk penunaian tugasnya dengan baik. Kebebasan tersebut dijamin oleh Negara demi kepentingan masyarakat. ${ }^{1}$

Tidak diragukan lagi, meskipun masyarakat abad ke-21 ini telah memasuki era globalisasi dan wacana penegakan hak asasi manusia telah berkembang sedemikian rupa, tetapi mengenai stigmatisasi seksualitas perempuan, tampaknya masih berakar kuat dalam budaya masyarakat. Pandangan yang dikotomis tersebut pada akhirnya membuat perempuan tidak mudah untuk mengakses hak-haknya, baik ketika masyarakat maupun aparat memposisikan perempuan sebagai korban kejahatan. ${ }^{2}$

Bela Negara adalah kewajiban setiap warga Negara Indonesia, hal tersebut telah diatur dalam Undang Undang Dasar Negara Republik Indonesia Tahun 1945, Pasal 27 ayat (3) mengamanatkan bahwa "Setiap warga negara berhak dan wajib ikut serta dalam upaya pembelaan negara". Upaya bela Negara saat ini disesuaikan dengan situasi dan kondisi yang dihadapi, setiap WNI dapat berpartisipasi dalam upaya tersebut sesuai dengan profesinya masing-masing. Oleh karenanya untuk tetap memupuk rasa kebangsaan sebagai salah satu nilai dasar bela Negara. Sebagai bagian dari warga negara Indonesia sudah seharusnya baik pekerja maupun perusahaan menerapkan nilai bela Negara seperti yang di amanatkan oleh Undang-Undang tersebut di atas. Hal tersebut dapat diwujudkan dengan cara menjaga kenyamanan bekerja, dimana kenyamanan akan mempengaruhi hubungan kerja yang kondusif. Salah Salah satu hal yang perlu diingat dalam menciptakan kenyamanan kerja adalah adanya kondisi kerja tanpa diskriminasi termasuk pelecehan seksual di tempat kerja. Dengan demikian, pekerjaan yang layak dalam pekerjaan yang cocok untuk semua didasarkan pada 4 (empat) pilar, yaitu dengan memprioritaskan prinsip-prinsip dan hak asasi manusia di

\footnotetext{
1 Maidin Gultom, Perlindungan Hukum terhadap Anak dan Perempuan, PT. Refika Aditama, Bandung, 2014, h. 75.

${ }^{2}$ Ibid., h. 67.
} 
tempat kerja (bebas dari kerja paksa, kebebasan berserikat, tanpa diskriminasi dan kebebasan dari pekerja anak), menyediakan perlindungan sosial terhadap risiko yang timbul dalam pelaksanaan tugas, tanpa mengurangi peluang kerja dan memberikan peluang untuk dialog sosial.

Dalam hal ini, negara memiliki fungsi untuk mendorong mewujudkan kenyamanan bagi warganya, terutama pekerja, dan juga bagi mereka yang rentan terhadap pelecehan seksual.

Pelecehan seksual dapat terjadi pada siapa saja. Pria dan wanita bisa menjadi korban atau pelaku perilaku yang dianggap kasar atau memalukan. Di tempat kerja, pelecehan seksual dapat terjadi antara karyawan / majikan dan karyawan lain (hubungan vertikal) atau antara karyawan dan karyawan (hubungan horizontal), antara pengusaha dan pekerja kontrak atau orang luar dan antara karyawan / penyedia layanan dan pelanggan / pihak ketiga. Perilaku yang tidak diinginkan tidak boleh berulang atau terus-menerus dan bisa menjadi satu pelecehan seksual.

Dalam kasus pelecehan seksual, sebagian besar korban adalah perempuan dan pelakunya adalah laki-laki. Tidak berarti bahwa tidak ada laki-laki yang mengalami pelecehan seksual, namun jumlah dan proporsinya tergolong kecil. ${ }^{3}$ Dengan demikian, urgensi membahas pelecehan seksual terhadap perempuan memang didukung fakta yang kuat tanpa harus menafikan kenyataan yang sebaliknya. Kejahatan kesusilaan atau moral offences dan pelecehan seksual atau sexual harassment merupakan dua bentuk pelanggaran atas kesusilaan yang bukan saja merupakan masalah hukum nasional suatu negara melainkan sudah merupakan masalah hukum semua negara di dunia atau merupakan masalah global. ${ }^{4}$ Begitu banyak kejahatan kekerasan yang terjadi dan menimpa kaum perempuan, sehingga perempuan sangat rentan menjadi korban kejahatan (victim of crime) di bidang kesusilaan. ${ }^{5}$ Banyaknya kekerasan yang terjadi terhadap perempuan di Indonesia, sebut saja "Tragedi di Bulan Mei Tahun 1998" yang disebut sebagai salah satu catatan bersejarah yang menempatkan pelanggaran hak asasi manusia terhadap perempuan yang luar biasa dahsyat kekejiannya, karena pada bulan itu diduga terjadi beragam bentuk sistemikasi, transparansi dan vulgarisasi kejahatan kekerasan dan pelecehan seksual. ${ }^{6}$

Tempat kerja merupakan salah satu tempat yang paling potensial bagi terjadinya pelecehan seksual.7 Fenomena pelecehan seksual di tempat kerja telah ada sejak wanita pertama kali memasuki dunia kerja. Meyer menyatakan secara umum ada tiga aspek

3 Offerman, LR. \& Malamut, AB., When Leaders Harash: The Impact of Target Perception of Organization Leadership and Climate in Harassment Reportingand Outcomes. Journal of Applied Psychology, 87(5), 2002, h. 885-893.

${ }^{4}$ Romli Atmasasmita, Kapita Selekta Hukum Pidana dan Kriminologi, Mandar Maju, Bandung, 1995, h. 103.

${ }^{5}$ Marcheyla Sumera, Perbuatan Kekerasan/Pelecehan Seksual Terhadap Perempuan, Lex et Societatis, Vol. I/No.2/ Apr-Jun/2013, Fakultas Hukum Universitas Sam Ratulangi, 2013, h. 40.

${ }^{6}$ Abdul Wahid dan Muhammad Irfan, Perlindungan Terhadap Korban Kekerasan Seksual, Refika Aditama, Bandung, 2001, h. 14-15.

7 Allgeier, E.R., \& Allgeier, A.R, Sexual Interaction, (3rd ed.). Lexington: Heath and Company D.C, 1991. 
penting dalam mendefinisikan pelecehan seksual yaitu :

a. Aspek perilaku, dimana perlu diketahui apakah hal itu merupakan proposisi seksual;

b. Aspek situasional, dimana perlu diketahui apakah ada perbedaan di mana atau kapan perilaku tersebut muncul; dan

c. Aspek legalitas, berarti dalam keadaan bagaimana perilaku tersebut dinyatakan ilegal. 8

Berdasarkan aspek perilaku, Farley ${ }^{9}$ mendefinisikan pelecehan seksual sebagai rayuan seksual yang tidak dikehendaki penerimanya, di mana rayuan tersebut muncul dalam beragam bentuk baik yang halus, kasar, terbuka, fisik maupun verbal dan bersifat searah. Bentuk umum dari pelecehan seksual adalah verbal dan godaan secara fisik di mana pelecehan secara verbal lebih banyak daripada secara fisik. Para ahli mengutip pelecehan verbal dalam bentuk persuasi seksual yang tidak diinginkan, lelucon terusmenerus atau pesan-pesan seksual, meminta tanggal tetap bahkan jika mereka ditolak, menghina atau menghina pesan, komentar provokatif atau cabul, ekspresi seksis tentang pakaian, tubuh, pakaian wanita atau aktivitas seksual, permintaan untuk layanan seksual diungkapkan dengan ancaman tidak langsung atau terbuka.

Pelecehan seksual dalam bentuk godaan fisik termasuk pandangan yang menunjukkan bagian tubuh (menatap payudara, pinggul atau bagian tubuh lainnya), pandangan menggoda dan mata yang berkedip, palpasi; termasuk mencubit, meremas, menggelitik, berpelukan, dan berciuman, pelecehan seksual seperti meraba-raba atau berciuman yang terjadi karena situasi yang sangat mendukung seperti di lift, koridor dan tempat-tempat sepi lainnya setelah bekerja, penawaran janji dengan imbalan promosi atau persuasi perempuan untuk mencium, dorongan seksual, tekanan halus untuk aktivitas seksual, percobaan perkosaan dan pemerkosaan diri. Dari sudut pandang situasional, pelecehan seksual dapat terjadi di mana saja dan dalam keadaan tertentu. Perempuan korban pelecehan seksual dapat berasal dari setiap ras, umur, karakteristik, status perkawinan, kelas sosial, pendidikan, pekerjaan, tempat kerja, dan pendapatan. ${ }^{10}$

Kekerasan/pelecehan seksual yang terjadi pada seorang perempuan dikarenakan sistem tata nilai yang mendudukkan perempuan sebagai makhluk yang lemah dan lebih rendah dibandingkan laki-laki, perempuan masih ditempatkan dalam posisi subordinasi dan marginalisasi yang harus dikuasai, dieksploitasi dan diperbudak laki-laki dan juga karena perempuan masih dipandang sebagai second class citizens. ${ }^{11}$

Pembangunan nasional dilakukan dalam konteks pengembangan masyarakat Indonesia secara keseluruhan dan pengembangan masyarakat Indonesia secara keseluruhan untuk menciptakan masyarakat yang sejahtera, adil, sejahtera, adil, baik

\footnotetext{
${ }^{8}$ Meyer, M.C., Berchtold, I.M., Oestrich, J., \& Collins, F. Sexual Harassment, New York: Princeton Petrocelly Book Inc, 1987.

${ }^{9}$ Farley, L., Sexual Shakedown: The Sexual Harassment of Women on The Job, New York: Mc Graw Hill, 1978.

${ }^{10}$ Higgins, L.P., \& Hawkins, J.W., Human Sexuality Across the Life Span: Implication for Nursing Practice. California: Woodsworth Health Science Division, 1986.

${ }^{11}$ Marcheyla Sumera, Op.Cit., h. 39.
} 
material maupun spiritual berbasis Pancasila dan UUD 1945. Dalam pelaksanaan pembangunan nasional, tenaga kerja memiliki peran dan posisi yang sangat penting sebagai agen dan tujuan pengembangan. Sejalan dengan peran dan posisi tenaga kerja, pengembangan pekerjaan diperlukan untuk meningkatkan kualitas tenaga kerja dan partisipasinya dalam pengembangan dan untuk meningkatkan perlindungan karyawan dan keluarga mereka sesuai dengan martabat dan martabat manusia. Perlindungan undang-undang ketenagakerjaan dimaksudkan untuk menjamin hak-hak dasar pekerja dan untuk memastikan kesempatan dan perlakuan yang sama tanpa diskriminasi atas dasar apa pun untuk memastikan kesejahteraan karyawan dan keluarga mereka sambil tetap mengikuti kemajuan dunia bisnis.

\section{Rumusan Masalah}

Masalah yang menjadi fokus penelitian ini yaitu perlindungan hukum terhadap pekerja yang menjadi korban pelecehan seksual dan sanksi terhadap pelaku pelecehan seksual.

\section{METODE PENELITIAN}

Berdasarkan latar belakang di atas, penelitian ini akan memeriksa dua formulasi masalah tentang bagaimana perlindungan hukum diberikan kepada korban pelecehan seksual dan pembatasan apa yang dikenakan pada pelecehan seksual sehingga perlindungan hak konstitusional dapat diimplementasikan.

Untuk menjawab permasalahan hukum dalam penelitian ini, maka dilakukan suatu penelitian hukum. Penelitian hukum merupakan suatu kegiatan know-how dalam ilmu hukum, penelitian hukum dilakukan untuk memecahkan isu hukum yang dihadapi. ${ }^{12}$ Metode penelitian yang digunakan dalam penelitian ini adalah metode penelitian hukum yuridis normatif. Metode penelitian yuridis normatif disebut juga dengan penelitian hukum kepustakaan adalah penelitian hukum yang dilakukan dengan cara meneliti bahan-bahan pustaka atau data sekunder. ${ }^{13}$ Data sekunder ini mencakup bahan hukum primer, sekunder, dan tersier. Pendekatan yang digunakan adalah pendekatan legislatif, pendekatan konseptual, dan pendekatan kasus. Untuk mendapatkan hasil penelitian yang dibenarkan secara ilmiah, penulis menggunakan teori perlindungan hukum dan teori tanggung jawab pidana.

\section{PEMBAHASAN}

\section{Perlindungan Hukum terhadap Pekerja yang Menjadi Korban Pelecehan Seksual}

Perlindungan hukum pekerja termasuk di dalamnya adalah pekerja perempuan. Yang dimaksudkan orang perempuan di sini adalah perempuan dianggap dewasa, Berarti Ini berarti seorang wanita yang berusia delapan belas tahun atau lebih (Pasal 76 ayat (1) Undang-Undang Nomor 13 Tahun 2003). Bagi seorang wanita, prinsip yang diterapkan adalah sama dengan prinsip untuk kaum muda, yang umumnya diizinkan

12 Peter Mahmud Marzuki, Penelitian Hukum, Edisi Revisi, Kencana Prenada Media Group, Jakarta, 2016, h. 60.

${ }^{13}$ Soerjono Soekanto dan Sri Mamudji, Penelitian Hukum Normatif, Suatu Tinjauan Singkat, PT. Raja Grafindo, Jakarta, 2013, h. 13. 
untuk melakukan pekerjaan, tetapi pembatasan diberlakukan. Mempekerjakan wanita di perusahaan tidak semudah yang Anda kira. Masih ada beberapa hal yang harus diperhatikan, mengingat perempuan umumnya bertenaga lemah, halus tapi tekun. Gunawi Kartasapoetra ${ }^{14}$ menulis bahwa:

a. Norma-norma susila harus diutamakan, agar tenaga kerja wanita tidak terpengaruh oleh perbuatan negatif dari tenaga kerja lawan jenisnya, terutama kalau dipekerjakan pada malam hari;

b. Para tenaga kerja perempuan umumnya mengerjakan pekerjaan-pekerjaan yang halus yang sesuai dengan kehalusan sifat dan tenaganya;

c. Para tenaga kerja itu ada yang masih gadis, ada pula yang sudah bersuami atau berkeluarga yang dengan sendirinya mempunyai beban-beban rumah tangga yang harus dilaksanakan pula.

Kelemahan-kelemahan seorang perempuan harus selalu diperhatikan oleh Perusahaan yang mempekerjakannya, karena bagaimanapun seorang pekerja juga dikatakan sebagai tulang punggung perusahaan. Tanpa karyawan, perusahaan tidak akan dapat berjalan, dan berpartisipasi dalam pengembangan.

Menyadari pentingnya karyawan bagi perusahaan, pemerintah, dan masyarakat, perlu dipikirkan agar karyawan dapat menjaga keselamatan mereka dalam melaksanakan pekerjaan. Demikian pula, perlu untuk memperjuangkan kedamaian dan kesehatan karyawan sehingga apa yang mereka hadapi dalam pekerjaan mereka dapat dipertimbangkan sebanyak mungkin, sehingga kewaspadaan mereka dalam melakukan pekerjaan dijamin. Pemikiran-pemikiran tersebut merupakan program perlindungan pekerja, yang dalam praktik sehari-hari berguna untuk dapat mempertahankan produktivitas dan kestabilan perusahaan. ${ }^{15}$

Keselamatan dan kenyamanan dalam bekerja adalah salah satu faktor yang mempengaruhi produktivitas kerja. Salah satu hal yang perlu kita perhatikan untuk menciptakan kenyamanan dalam bekerja adalah ketika kondisi kerja yang tidak mendiskriminasi pekerja perempuan termasuk pelecehan seksual di tempat kerja yang sering kita hadapi dan kejahatan yang sering menimpa pekerja perempuan di Indonesia. Pelecehan seksual di tempat kerja adalah perilaku yang mengarah pada masalah seksual yang tidak disetujui oleh korban. Sampai masyarakat memiliki hak untuk mengkritiknya dan mengekspresikan penolakannya terhadap perilaku dalam bentuk penderitaan yang disengaja yang diberikan karena perilaku itu.

Sejatinya mengenai bentuk perlindungan hukum yang diberikan Pemerintah kepada pekerja yang menjadi korban pelecehan seksual telah tertuang dalam Pasal 86 UU Ketenagakerjaan yang menyatakan bahwa :

(1) Setiap pekerja/buruh mempunyai hak untuk memperoleh perlindungan atas :

a. keselamatan dan kesehatan kerja;

${ }^{14}$ H. Zaeni Asyhadie dan Rahmawati Kusuma, Hukum Ketenagakerjaan Dalam Teori dan Praktik di Indonesia, Prenadamedia Group, Jakarta, 2019, h. 134

15 Zainal Asikin, Agusfian Wahab, Lalu Husni, dkk, Dasar-Dasar Hukum Perburuhan, Raja Grafindo Persada, Jakarta, 2016, h.96 
b. moral dan kesusilaan; dan

c. perlakuan yang sesuai dengan harkat dan martabat manusia serta nilai-nilai agama.

(2) Untuk melindungi keselamatan pekerja/buruh guna mewujudkan produktivitas kerja yang optimal diselenggarakan upaya keselamatan dan kesehatan kerja.

(3) Perlindungan sebagaimana dimaksud dalam ayat (1) dan ayat (2) dilaksanakan sesuai dengan peraturan perundang- undangan yang berlaku.

Dalam menangani pelecehan seksual di tempat kerja, wanita merespons berbagai reaksi. Tiga faktor yang menentukan bentuk reaksi perempuan terhadap pelecehan seksual yaitu faktor kebutuhan ekonomi di mana perempuan memerlukan penghasilan untuk mengelola kehidupannya sehari-hari, faktor struktur dalam tempat kerja di mana laki-laki biasanya menduduki peringkat lebih tinggi di tempat kerja, dan faktor pembiasaan peran jenis perempuan di mana masyarakat melatih perempuan untuk senantiasa berperilaku "manis". 16

Berdasarkan ketiga faktor di atas, reaksi terhadap pelecehan seksual pada individu secara umum adalah mengabaikan pelecehan dengan risiko pelecehan berlanjut atau memburuk, meminta untuk ditransfer dalam bentuk reaksi verbal, menerimanya, menerimanya karena takut ditolak akan mengakibatkan pembalasan dalam bentuk pembatasan organisasi pelaku pelecehan atau karyawan atau mengajukan keluhan kepada majikan.

Reaksi manajemen atau organisasi terhadap pelecehan seksual secara umum adalah untuk mengatasi masalah ini berdasarkan kasus per kasus. Salah satu caranya adalah dengan meminta pria untuk menghentikan tindakan mereka dan meminta wanita yang menjadi korban untuk tidak mengganggu diri mereka sendiri. Metode ini adalah metode pemecahan gaya pria. Akibatnya, perempuan merasa tidak puas dan merasa tidak berguna dalam mengangkat masalah ini, sehingga laporan kasus pelecehan seksual rendah. Lebih buruk lagi, manajemen itu sendiri sering tidak mengambil tindakan.

Alasan utama untuk tidak melakukan sesuatu adalah (1) Manajemen yang ceroboh untuk menangani masalah dengan serius atau diabaikan untuk mengidentifikasi pelecehan seksual sebagai masalah serius, (2) Organisasi tidak memiliki kebijakan atau pedoman yang jelas. Hal ini menyebabkan organisasi menjadi ambigu tentang pelecehan seksual, (3) Ada kebingungan tentang siapa di dalam organisasi yang bertanggung jawab atas masalah ini. Tanggapan lain dari organisasi adalah lebih fokus pada cara-cara untuk mencegah pelecehan seksual di masa depan daripada mendeteksi dan mengintimidasi mereka dengan segera.

Masalahnya adalah, jika organisasi lambat bertindak seperti ini maka pelecehan seksual ditempatkan sebagai masalah yang kurang serius. Situasi seperti itu juga berlaku di Indonesia. Di Indonesia, fenomena pelecehan seksual relatif baru. Berbagai faktor mencegah munculnya fenomena ini ke permukaan, terutama faktor individu. Para korban pelecehan seksual dihadapkan dengan pilihan kerugian yang sama menyakitkan yang ditimbulkan sebagai akibat dari pelecehan seksual dan rasa malu jika masalahnya

16 Sri Kurnianingsih, Pelecehan Seksual Terhadap Perempuan Di Tempat Kerja, Buletin Psikologi, ISSN : 0854 - 7108 Tahun XI, No. 2, Desember 2003 , h. 125 
diumumkan. Tidak adanya prosedur dan peraturan hukum yang jelas di Indonesia mengenai pelecehan seksual menyebabkan masalah pelecehan seksual yang tidak memuaskan. Akibatnya, korban pelecehan seksual memilih untuk menyelesaikan masalah di luar hukum, seperti membuat perdamaian dalam keluarga, menarik diri dari pekerjaan atau mengabaikan gangguan dengan risiko efek psikologis yang mempengaruhi kinerja mereka.

Pada dasarnya, banyak hal yang bertentangan dengan latar belakang atau pengaruh karyawan yang mendapatkan tindakan mengganggu yang tidak mengambil tindakan hukum atau mengeluh kepada organisasi terkemuka. Alasannya adalah ada rasa takut, malu, tidak tahu ke mana harus mengeluh, takut tidak diperhatikan lagi, bahkan jika pekerja perempuan takut kehilangan pekerjaannya atau dipecat. Faktor inilah yang membuat pelecehan seksual begitu sering dianggap berita biasa bagi perusahaan karena kurangnya respons serius dari perusahaan dan pemerintah. Sementara negara memiliki fungsi atau upaya untuk mendorong realisasi bagi orang Indonesia, terutama pekerja perempuan yang sangat rentan terhadap pelecehan seksual. Oleh karena itu, ada kebutuhan untuk kepedulian kita bersama untuk menciptakan kenyamanan bekerja melalui pencegahan pelecehan seksual di tempat kerja untuk membangun hubungan industrial yang harmonis.

\section{Sanksi Terhadap Pelaku Pelecehan Seksual dalam Mewujudkan Bela Negara}

Pertanggungjawaban pidana disebut sebagai responsibility, atau criminal liability. Konsep pertanggungjawaban pidana tidak hanya soal hukum semata-mata melainkan juga menyangkut soal nilai-nilai moral atau kesusilaan umum yang dianut oleh suatu masyarakat atau kelompok-kelompok dalam masyarakat, hal ini dilakukan agar pertanggungjawaban pidana tercapai dengan memenuhi keadilan. ${ }^{17}$

Tanggung jawab pidana mengandung asas pelanggaran (asas pelanggaran). Meskipun pada prinsipnya tanggung jawab pidana didasarkan pada rasa bersalah, dalam beberapa kasus, ini tidak mengesampingkan kemungkinan mendelegasikan kewajiban dan tanggung jawab yang ketat. . Masalah kesesatan (error) baik kesesatan mengenai keadaannya (error facti) maupun kesesatan mengenai hukumnya sesuai dengan konsep merupakan salah satu alasan pemaaf sehingga pelaku tidak dipidana kecuali kesesatannya itu patut dipersalahkan kepadanya. ${ }^{18}$

Menurut Roeslan Saleh pertanggungjawaban pidana diartikan sebagai diteruskannya celaan yang objektif yang ada pada perbuatan pidana dan secara subjektif memenuhi syarat untuk dapat dipidana karena perbuatannya itu. ${ }^{19}$

Seseorang akan memiliki sifat tanggung jawab pidana jika sesuatu atau tindakan yang dilakukannya bertentangan dengan hukum, tetapi seseorang dapat kehilangan sifat

\footnotetext{
${ }^{17}$ Hanafi, Mahrus, Sistem Pertanggung Jawaban Pidana, Cetakan Pertama, Jakarta, Rajawali Press, 2015, h. 16.

${ }_{18}$ Barda Nawawi Arief, Masalah Penegakan Hukum dan Kebijakan Penanggulangan Kejahatan, Bandung: PT. Citra Aditya Bakti, 2001, h. 23.

19 Roeslan Saleh, Pikiran-Pikiran Tentang Pertanggung Jawaban Pidana, Cetakan Pertama, Jakarta, Ghalia Indonesia, h. 33.
} 
tanggung jawab jika dalam dirinya menemukan elemen yang menyebabkan hilangnya kemampuan seseorang untuk bertanggung jawab. Pada hakikatnya pertanggungjawaban pidana adalah suatu bentuk mekanisme yang diciptakan untuk bereaksi atas pelanggaran suatu perbuatan tertentu yang telah disepakati. ${ }^{20}$

Untuk orang yang melakukan pelanggaran atau tindak pidana, prinsip-prinsip hukum pidana diperlukan. Salah satu prinsip hukum pidana adalah prinsip hukum nullum delictum nulla poena sine pravia lege poenali atau sering disebut sebagai prinsip validitas, prinsip ini menjadi prinsip dasar yang tidak tertulis dalam penuntutan pidana seseorang yang telah melakukan tindak pidana "tidak dihukum jika tidak ada kesalahan". Ini berarti bahwa seseorang hanya dapat dimintai pertanggungjawaban jika orang tersebut melakukan pelanggaran atau melakukan sesuatu yang melanggar hukum dan peraturan. Untuk menentukan keberadaan suatu tindak pidana sebaiknya tidak menggunakan metafora, dan aturan hukum pidana tidak surut. Karena itu, dalam pertanggungjawaban pidana ada dua hal yang harus diperhatikan, yaitu tindak pidana dan pelaku tindak pidana.

Berkaitan dengan pertanggungjawaban pidana, ada beberapa hal yang penting dicatat di bawah ini yaitu: 21

a. Melakukan tindak pidana;

Parameter seseorang dinyatakan melakukan tindak pidana, harus dilihat apakah perbuatan, tindakan, kegiatan atau aktivitas seseorang tersebut sudah ada atau belum ada aturannya. 22

b. Adanya kemampuan bertanggung jawab

Kemampuan untuk mengambil tanggung jawab harus dibuktikan dengan ada atau tidak adanya Hakim, karena jika seseorang terbukti tidak memiliki kemampuan untuk mengambil tanggung jawab, ini menjadi dasar dari tidak bertanggung jawabnya pelaku, yang berarti bahwa pelaku tidak dapat dihukum.

Kitab Undang-Undang Hukum Pidana tidak mengatur tentang kemampuan bertanggung jawab namun yang diatur dalam KUHP sendiri justru kebalikan dari kemampuan bertanggungjawab.23 Pasal yang mengatur tentang kebalikan dari kemampuan bertanggung jawab adalah pasal 44 KUHP yang berbunyi:

1. Barang siapa melakukan perbuatan yang tidak dapat dipertanggung jawabkan padanya, disebabkan karena jiwanya cacat dalam tumbuhnya (gebrekkige ontiwikkeling) atau terganggu karena penyakit, tidak dipidana;

2. Jika ternyata bahwa perbuatan tidak dapat dipertanggung jawabkan padanya disebabkan karena jiwanya cacat dalam tumbuhnya atau terganggu karena penyakit, maka Hakim dapat memerintahkan supaya orang itu dimasukkan kedalam rumah sakit jiwa, paling lama satu tahun sebagai waktu percobaan.

${ }^{20}$ Chairul Huda, Dari Tindak Pidana Tanpa Kesalahan Menuju Kepada Tiada Pertanggungjawaban Pidana Tanpa Kesalahan, Cetakan ke-2, Jakarta, Kencana, 2006, h. 68.

${ }^{21}$ Didik Endro Purwoleksono, Hukum Pidana, Airlangga University Press, Surabaya, 2013, h. 63.

22 Ibid., h.64.

${ }^{23}$ Andi Zainal Abidin, Hukum Pidana I, cetakan ke-2, Sinar Grafika, Jakarta , 2007, h. 260. 
Dalam Pasal 44 KUHP ini seseorang yang melakukan tindak pidana tidak dapat bertanggungjawab atas perbuatan yang telah ia lakukan apabila tidak memiliki unsur kemampuan bertanggungjawab, ketidak mampuan untuk bertanggungjawab apabila didalam diri pelaku terdapat kesalahan, kesalahan tersebut ada 2 yaitu:

1. Dalam masa pertumbuhan pelaku, pelaku mengalami cacat mental, sehingga hal itu mempengaruhi pelaku untuk membedakan antara perbuatan yang baik adan buruk.

2. Jika jiwa pelaku mengalami gangguan kenormalan yang disebabkan suatu penyakit, sehingga akalnya kurang berfungsi secara optimal atau akalnya tidak berfungsi secara optimal untuk membedakan hal-hal yang baik dan buruk.

c. Dengan kesengajaan atau kealpaan;

Alasan pemaaf dalam hukum pidana adalah tidak mampu bertanggungjawab, daya paksa, dan pembelaan terpaksa melampaui batas. ${ }^{24}$ Daya paksa dalam KUHP diatur didalam Pasal 48 yang menyatakan bahwa barang siapa seseorang yang melakukan suatu tindak pidana karena atas dorongan daya paksa, maka tidak dapat dipidana.

d. Tidak ada alasan pemaaf.

Menurut KUHP alasan pemaaf ialah alasan yang menghapus kesalahan terdakwa, jadi di sini perbuatan terdakwa tetap merupakan tindak pidana, tetapi tidak dapat dipidana karena tidak ada kesalahan.

Pelecehan seksual adalah tindakan seksual yang tidak diinginkan, permintaan untuk melakukan tindakan seksual, tindakan verbal atau fisik atau gerakan seksual, atau perilaku seksual lainnya, yang membuat seseorang merasa tersinggung, terhina dan / atau terintimidasi ketika reaksi masuk akal dalam situasi dan keadaan yang ada, dan tindakan-tindakan semacam itu mengganggu pekerjaan, digunakan sebagai persyaratan kerja atau menciptakan lingkungan kerja yang mengintimidasi, bermusuhan, atau tidak sopan.

Pelecehan seksual dapat terjadi pada siapa saja. Pria dan wanita bisa menjadi korban atau pelaku perilaku yang dianggap kasar, memalukan atau mengintimidasi. Tindakan ini dapat terjadi antara karyawan / majikan dan karyawan lain (hubungan vertikal) atau antara karyawan dan karyawan (hubungan horizontal), antara majikan dan karyawan kontrak atau orang luar dan antara karyawan / penyedia layanan dan pelanggan / pihak ketiga. Perilaku yang tidak diinginkan ini tidak boleh berulang atau gigih dan bisa menjadi peristiwa yang bisa menjadi pelecehan seksual.

Pelecehan seksual memiliki berbagai bentuk. Secara luas, terdapat lima bentuk pelecehan seksual yaitu: ${ }^{25}$

1. Pelecehan fisik termasuk sentuhan yang tidak diinginkan mengarah ke perbuatan

${ }^{24}$ Schaffmeister, Keijzer, Sutorius, Hukum Pidana, Cetakan Pertama, Liberty, Yogyakarta, 1995, h. 67.

${ }^{25}$ Kementerian Tenaga Kerja dan Transmigrasi \& Organisasi Perburuhan Internasional, Pedoman Pencegahan Pelecehan Seksual di Tempat Kerja, Diterbitkan Berdasarkan Surat Edaran Menteri Tenaga Kerja dan Transmigrasi No. SE.03/MEN/IV/2011, Indonesia, 2011, h. 9. 
seksual seperti mencium, menepuk, mencubit, melirik atau menatap penuh nafsu;

2. Pelecehan lisan termasuk ucapan verbal/ komentar yang tidak diinginkan tentang kehidupan pribadi atau bagian tubuh atau penampilan seseorang, lelucon dan komentar bernada seksual;

3. Pelecehan isyarat termasuk bahasa tubuh dan atau gerakan tubuh bernada seksual, kerlingan yang dilakukan berulang-ulang, isyarat dengan jari, dan menjilat bibir;

4. Pelecehan tertulis atau gambar termasuk menampilkan bahan pornografi, gambar, screensaver atau poster seksual, atau pelecehan lewat email dan moda komunikasi elektronik lainnya;

5. Pelecehan psikologis/emosional terdiri atas permintaan-permintaan dan ajakan-ajakan yang terus menerus dan tidak diinginkan, ajakan kencan yang tidak diharapkan, penghinaan atau celaan yang bersifat seksual.

Pekerja perempuan di berbagai daerah di Indonesia masih mengalami diskriminasi di tempat kerja. Bentuk-bentuk diskriminasi bervariasi dari perbedaan pekerjaan hingga pelecehan seksual. Federasi Pekerja Lintas-Pabrik (FBLP) menyatakan bahwa pelecehan seksual terjadi di banyak pabrik garmen. Alasannya adalah bahwa 99 persen pekerja di pabrik garmen adalah perempuan. Ketua FBLP Jumisih mengatakan kerusakan terjadi karena kondisi yang tidak setara antara pekerja perempuan dan pekerja laki-laki. Ini tidak hanya dilakukan oleh rekan kerja pria, gangguan juga dilakukan oleh mekanik dan penyelia.. Kalau buruh perempuan menolak, ancamannya diputus kontrak atau beban pekerjaan ditambah, buruh perempuan yang umumnya berlatar belakang ekonomi rendah terpaksa menuruti niat jahat rekan kerja laki-laki mereka. Adapun perlakukan perlecehan yang sering dilakukan oleh pekerja dalam hal ini atasan : ${ }^{26}$

a. Perlakuan tak sopan seperti diraba-raba;

b. Diintip saat buang air kecil;

c. Dipaksa kencan;

d. Hingga diperkosa sampai hamil.

Jumusih mengatakan, itu adalah hal biasa bagi pekerja perempuan. Tidak jarang para pekerja perempuan ini juga menerima kekerasan fisik dengan memukul, melempar benda-benda keras, dan dipukuli oleh meja tempat mereka bekerja. Jumisih mengatakan karyawan sering mengalami kesulitan mengeluh tentang perawatan. Mereka trauma dan menganggapnya sangat memalukan sehingga mereka tidak berani melaporkannya kepada orang lain. Padahal, katanya, perlindungan tenaga kerja telah diatur dalam UU Ketenagakerjaan. Kita harus terus-menerus meminta pekerja perempuan untuk mencari tahu tentang kasus ini. Mereka tidak mau menceritakan kisah mereka sendiri, katanya. Selain beberapa perawatan yang tidak menyenangkan, pekerja perempuan juga sering mengalami kesulitan mendapatkan cuti haid atau hamil dari tempat kerja mereka. Jumisih menjelaskan, dalam pasal 81 UU Ketenagakerjaan, ketentuan tentang cuti haid

26 Dikutip dari https://www.cnnindonesia.com/nasional/20161124152933-20-175048/buruhpabrik-garmen-sering-alami-kekerasan-seksual di akses pada tanggal 25 Desember 2018 pada pukul $11.00 \mathrm{Wib}$. 
bagi pekerja perempuan diatur. Pada cuti hamil, katanya, pekerja perempuan harus mendapatkan kuota enam bulan. Ransum liburan ini dibagi setelah melahirkan dan bulan pertama ketika mereka hamil. Namun pada kenyataannya, rata-rata pekerja perempuan hanya diberikan cuti hamil selama tiga bulan. Alih-alih mendapat cuti, karyawan justru diminta mengundurkan diri. Tidak sedikit pekerja wanita akhirnya meninggal selama kehamilan karena kelelahan kerja. Situasi ini membuat posisi pekerja perempuan lebih sulit di tempat kerja. Padahal, menurut Jumisih, pekerja perempuan itu harus bekerja karena suaminya tidak mendapat gaji yang cukup. Kondisi yang kondusif dalam hubungan industrial harus dijaga terutama oleh karyawan/buruh dan manajemen, oleh karena itu komunikasi yang lancar berdasarkan niat baik (itikad baik) baik pekerja / buruh maupun karyawan adalah sesuatu yang sangat diperlukan. Kenyamanan bekerja untuk karyawan/buruh dalam melaksanakan pekerjaannya akan tercapai jika lingkungan kerja yang aman, kondusif, efektif dan produktif selalu dijaga.Untuk menjaga kondisi yang demikian, salah satunya harus dijaga untuk tidak terjadi perbuatan asusila di tempat kerja termasuk tindakan pelecehan seksual di tempat kerja. Pelecehan seksual apabila ditinjau dari Kitab Undang-Undang Hukum Pidana merupakan delik aduan, sehingga harus ada pengaduan dari korban atau pihak yang mengetahui, bentuk-bentuk pelecehan seksual yang mengarah pada delik aduan sebagaimana KUH Pidana antara lain :27

1. Kekerasan dengan paksaan untuk melakukan persetubuhan (Pasal 285 KUHP)

2. Perbuatan yang tidak menyenangkan yang melanggar norma kesopanan, seperti perbuatan pencabulan, mencium, meraba anggota kemaluan atau ke arah dada.

Sementara itu, tindakan kesusilaan yang diatur dalam KUHP adalah kesopanan yang dilakukan dan dirasakan oleh masyarakat dapat menyebabkan pelanggaran dari tindakan tidak bermoral seperti orang mandi hampir telanjang di pemandian umum. Para korban tindakan tidak bermoral memiliki hak untuk mengajukan tuntutan pidana dan/atau perdata terhadap pelaku.

Tanggung jawab perusahaan adalah komitmen bisnis untuk bertindak secara etis, beroperasi secara legal dan berkontribusi pada pertumbuhan ekonomi sambil meningkatkan kualitas kehidupan karyawan dan masyarakat setempat. Ini juga merupakan konsep bahwa organisasi dan perusahaan memiliki tanggung jawab terhadap konsumen, karyawan, pemegang saham, masyarakat dan lingkungan dalam semua aspek operasi perusahaan. Bentuk tanggung jawab disesuaikan dengan objek masing-masing. Perusahaan bertanggung jawab kepada karyawan untuk memenuhi hak-hak mereka. Salah satu bentuk tanggung jawab perusahaan adalah tanggung jawab pidana di mana satu bentuk tanggung jawab adalah untuk menentukan apakah tersangka atau terdakwa, dalam hal ini, dapat menjadi karyawan atau pejabat perusahaan. Dimana mereka bertangung jawab atas suatu tindak pidana yang telah terjadi kepada korban yang biasanya adalah rekan kerja. Seseorang disebut telah melakukan perbuatan pidana, apabila perbuatannya terbukti sebagai perbuatan pidana seperti yang telah diatur dalam

${ }^{27}$ Kementerian Tenaga Kerja dan Transmigrasi \& Organisasi Perburuhan Internasional, Op. Cit., h. 10. 
peraturan perundang-undangan pidana yang berlaku. Akan tetapi seseorang yang telah terbukti melakukan suatu perbuatan pidana tidak selalu dapat dijatuhi pidana. Hal ini dikarenakan dalam pertanggung jawaban pidana, tidak hanya dilihat dari perbuatannya saja, melainkan dilihat juga dari unsur kesalahannya.

Setiap langkah untuk menyelesaikan pelecehan seksual di tempat kerja harus memenuhi prinsip keadilan. Selain itu, harus ada keseimbangan informasi dari korban dan juga pelecehan seksual yang dituduhkan. Pelaku diduga mendapat informasi yang baik tentang pengaduan dari korban dan diberi kesempatan untuk menanggapi. Sementara itu, korban diberi kesempatan untuk mengutarakan pengaduan mereka dan menemukan jawaban yang diharapkan dari pelaku terhadap pengaduan dari korban.

Setiap langkah untuk menyelesaikan pelecehan seksual di tempat kerja harus memenuhi prinsip keadilan. Selain itu, harus ada keseimbangan informasi dari korban dan juga pelecehan seksual yang dituduhkan. Pelaku diduga mendapat informasi yang baik tentang pengaduan dari korban dan diberi kesempatan untuk menanggapi. Sementara itu, korban diberi kesempatan untuk mengutarakan pengaduan mereka dan menemukan jawaban yang diharapkan dari pelaku terhadap pengaduan dari korban..

Pengusaha harus membuat prosedur penanganan pengaduan yang sesuai dengan tempat kerja masing-masing. Prosedur penanganan pengaduan yang paling efektif menyediakan berbagai opsi untuk menangani pelecehan seksual. Misalnya, seseorang dapat mengadu ke atasannya sendiri, manajer lain atau petugas yang menangani pengaduan yang ditunjuk. Korban dapat memilih opsi yang paling sesuai dengan keadaan kasus. Dalam menawarkan opsi, harus memastikan bahwa manajer memiliki pengetahuan dan pelatihan untuk menangani keluhan pelecehan seksual dan harus memberi tahu staf bahwa keluhan dapat diajukan ke Komisi / divisi di perusahaan. Prosedur penanganan pengaduan dapat dilakukan melalui pengaduan formal dan informal yang menekankan solusi atau penyelesaian masalah dari bukti faktual atau bukti pengaduan sementara prosedur formal fokus pada pembuktian apakah pengaduan dapat dibuktikan.

Karyawan harus diberi kesempatan untuk memilih untuk menyelesaikan keluhan dalam menangani pelecehan seksual melalui prosedur formal atau informal. Untuk melakukan penelitian, komite pencegahan pelecehan seksual dapat dibentuk. Komite resolusi perselisihan kecil harus seimbang gender dan anggotanya terdiri dari manajemen senior, staf yang terlatih untuk menangani kasus pelecehan seksual.

Untuk memberikan efek pencegahan, perlu untuk meresepkan bentuk tindakan dan batasan disiplin. Mekanisme dan prosedur untuk mengambil tindakan disipliner atau pembatasan terhadap mereka yang terkait dapat diatur dan disepakati dalam peraturan perusahaan dan / atau perjanjian kerja sama.

Pembatasan harus sepadan dengan tingkat pelecehan seksual dan sesuai dengan ketentuan yang berlaku di perusahaan. Jika dugaan pelecehan seksual tidak memiliki bukti kuat, majikan harus memastikan bahwa orang yang mengeluh tidak dibatasi. Pembalasan adalah masalah penting jika tersangka adalah bos korban. Pengusaha perlu bekerja untuk memastikan kerahasiaan selama proses investigasi dan menjaga 
keselamatan pengadu. Sebagai bagian dari langkah-langkah tindak lanjut, petugas yang bertugas mengawasi pelecehan seksual di kantor dari waktu ke waktu harus memeriksa pelapor untuk memastikan tidak ada pembalasan.

Dalam hal korban pelecehan seksual menderita kerugian akibat pelecehan seksual, seperti penurunan pangkat, penolakan promosi yang mengakibatkan kerugian uang karena penolakan tunjangan dalam hubungan kerja, maka perlu tindakan pengembalian korban ke kedudukan semula. Bila pengaduan ternyata tidak berdasar, pihak pengadu berkewajiban untuk memulihkan nama baik pihak terduga.

\section{PENUTUP}

Keselamatan dan kenyamanan dalam bekerja adalah salah satu faktor yang mempengaruhi produktivitas kerja. Salah satu hal yang perlu kita perhatikan untuk menciptakan kenyamanan dalam bekerja adalah ketika kondisi kerja yang tidak mendiskriminasi pekerja perempuan termasuk pelecehan seksual di tempat kerja yang sering kita hadapi dan kejahatan yang sering menimpa pekerja perempuan di Indonesia. Pelecehan seksual di tempat kerja adalah perilaku yang mengarah pada masalah seksual yang tidak disetujui oleh korban. Sampai masyarakat memiliki hak untuk mengkritiknya dan mengekspresikan penolakannya terhadap perilaku dalam bentuk penderitaan yang disengaja yang diberikan karena perilaku itu. Dalam menangani pelecehan seksual di tempat kerja, wanita merespons berbagai reaksi. Di Indonesia, fenomena pelecehan seksual relatif baru. Berbagai faktor mencegah munculnya fenomena ini ke permukaan, terutama faktor individu. Para korban pelecehan seksual dihadapkan dengan pilihan kerugian yang sama menyakitkan yang ditimbulkan sebagai akibat dari pelecehan seksual dan rasa malu jika masalahnya diumumkan. Pada dasarnya, banyak hal yang bertentangan dengan latar belakang atau pengaruh karyawan yang mendapatkan tindakan mengganggu yang tidak mengambil tindakan hukum atau mengeluh kepada organisasi terkemuka. Alasannya adalah ada rasa takut, malu, tidak tahu ke mana harus mengeluh, takut tidak diperhatikan lagi, bahkan jika karyawan wanita itu takut kehilangan pekerjaannya atau dipecat. Faktor inilah yang membuat pelecehan seksual sering dianggap sebagai berita biasa bagi perusahaan karena tidak ada respons serius dari perusahaan dan pemerintah.

Pelecehan seksual adalah tindakan seksual yang tidak diinginkan, permintaan untuk melakukan tindakan seksual, tindakan verbal atau fisik atau gerakan seksual, atau perilaku seksual lainnya, yang membuat seseorang merasa tersinggung, terhina dan/atau terintimidasi ketika reaksi masuk akal dalam situasi dan keadaan yang ada, dan tindakan-tindakan semacam itu mengganggu pekerjaan, digunakan sebagai persyaratan kerja atau menciptakan lingkungan kerja yang mengintimidasi, bermusuhan, atau tidak sopan. Setiap langkah untuk menyelesaikan pelecehan seksual di tempat kerja harus memenuhi prinsip keadilan. Selain itu, harus ada keseimbangan antara kedua korban dan juga apa yang dikatakan sebagai intimidasi seksual. Tersangka pelaku diberi pemberitahuan keluhan dari korbannya dan diberi kesempatan untuk menanggapi. Dalam pertanggungjawaban pidana, ada dua kasus yang harus diperhatikan, yaitu 
tindak pidana dan masalah pidana.

\section{DAFTAR PUSTAKA}

Buku:

Andi Zainal Abidin. (2007). Hukum Pidana I. Cetakan ke-2, Jakarta: Sinar Grafika

Barda Nawawi Arief. (2001). Masalah Penegakan Hukum dan Kebijakan Penanggulangan

Kejahatan, Bandung: PT. Citra Aditya Bakti

Chairul Huda. (2006). Dari Tindak Pidana Tanpa Kesalahan Menuju Kepada Tiada

Pertanggung jawaban Pidana Tanpa Kesalahan, Cetakan ke-2, Jakarta: Kencana

Didik Endro Purwoleksono. (2013). Hukum Pidana, Surabaya: Airlangga University Press.

Hanafi dan Mahrus. (2016). Sistem Pertanggung Jawaban Pidana, Cetakan Pertama, Jakarta: Rajawali

H. Zaeni Asyhadie dan Rahmawati Kusuma. (2019). Hukum Ketenagakerjaan dalam

Teori dan Praktik di Indonesia, Jakarta: Prenadamedia Group

Maidin Gultom. (2014). Perlindungan Hukum terhadap Anak dan Perempuan, Bandung: PT. Refika Aditama

Meyer, M.C., Berchtold, I.M., Oestrich, J., \& Collins, F. (1987). Sexual Harassment, New York: Princeton Petrocelly Book Inc

Peter Mahmud Marzuki. (2016). Penelitian Hukum, Edisi Revisi, Jakarta: Kencana Prenada Media Group.

Roeslan Saleh. Pikiran-Pikiran tentang Pertanggung Jawaban Pidana, Cetakan Pertama, Jakarta: Ghalia Indonesia.

Romli Atmasasmita. (1995). Kapita Selekta Hukum Pidana dan Kriminologi, Bandung: Mandar Maju

Schaffmeister, Keijzer, Sutorius. (1995). Hukum Pidana, Cetakan Pertama, Yogyakarta: Liberty

Soerjono Soekanto dan Sri Mamudji. (2013). Penelitian Hukum Normatif, Suatu Tinjauan Singkat, Jakarta: PT. Raja Grafindo

Zainal Asikin, Agusfian Wahab, Lalu Husni, dkk. (2016). Dasar-Dasar Hukum Perburuhan, Jakarta: Raja Grafindo Persada

Jurnal:

Marcheyla Sumera. (2014). Perbuatan Kekerasan/Pelecehan Seksual terhadap Perempuan, Lex et Societatis, Vol. I/No.2/ Apr-Jun/2013. 